\title{
There is Soil, There is Wealth - Factors to Influence Urban Citizens to Purchase Farmland and Farmhouse in Taiwan
}

\author{
Jung-Tsun Liu
}

\begin{abstract}
This research plans to explore factors of urban citizens' farmland purchasing and farmhouse building in rural area based on theory of planned behavior. This research also collected 750 effective questionnaires from municipalities including Taipei City, Taichung City and Kaohsiung City for analysis. Research result indicates that: citizens will have more willingness to purchase farmland in a certain area as long as they expect the value of farmland will increase. As a result, attitude is the strongest factor influencing survey candidates' willingness to purchase farmland and build farmhouses. Before land purchasing and farmhouse building, survey candidates will first seek opinions from their most trusted and closest citizens. Next, they will rely on information technology. This research also provides suggestions to related competent authorities for reference purpose.
\end{abstract}

Index Terms-Farmland, farmhouse, the theory of planned behavior.

\section{INTRODUCTION}

After the modification of Agriculture Development Act (hereinafter referred to as "Agriculture Act") in 2000, there are huge changes on farm land utilization policy in Taiwan. These changes include easing of farmland free transaction, easing of limits over arable land division, conditional building of agriculture facilities or farmhouses, energize farmland leasing, efficient utilization system as well as reasonable and orderly releasing of farmland [1].

After the modification of Agriculture Act, farmland free transaction spirit has brought market mechanism back to farmland market. This is extremely important to the price and quantity information of market mechanism. However, with respect to social phenomenon incurred after the passing of Agriculture Act, [2] pointed out that it is already an inarguable fact that citizens living in farmhouses are not all peasants. Living functions provided by farmhouses are same as the ones provided by resident houses. With this, [3] is also considering the possibility to position farmland as a low density and high quality resident community.

In addition to aforementioned easing on farmland transaction limits after the passing of Agriculture Act, rural villages are also facing problems of aging population, young generation's outward migration as well as rural community's gradual urbanization. These have indirectly boosted even more peasants' selling of their own land. Furthermore, there is a trend in Taiwan that urban citizens relocate to rural area to purchase land, build farmhouse, travel for leisure purpose or lead a rural life which is different from retirement life. Reason for such phenomenon

Manuscript received October 18, 2014; revised January 15, 2014.

The author is with Chang Jung Christian University, Institute of Management PhD, Taiwan (R.O.C.) (email: 1tu0283691588@gmail.com). is because citizens in urban area have more disposal income and time to purchase land in rural area. Additionally, most rural areas in Taiwan still maintain good natural landscape and living in rural village will allow citizens to enjoy a life different from the fast speed urban life. Population in rural area is relatively smaller and both water and air are relatively cleaner. Besides, Taiwan has excellent highway networks and related roads connecting urban areas and rural areas and it only takes about an hour to go from rural area to urban area. All these factors combined have enhanced urban citizens' willingness to consider land purchasing and farmhouse building in rural area.

\section{AJZEN's THEORY OF PLANNED BEHAVIOR}

During the past decade, Theory of Planned Behavior ("TPB") has been utilized in analyzing psychology theories of human and behavior research both in the U.S. and Taiwan [4]-[9]. ТPB was presented by [10], [11]. This theory contends that an individual's behavior is mainly determined by his/her behavioral intention ("BI") which is then mainly influenced by Attitude toward Behavior ("AT"), Subjective Norm ("SN") and Perceived Behavioral Control ("PBC"). Ajzen considered that Behavior Intention ("BI") is a perception activity which reflects an individual's willingness and conscious plans to be engaged in certain behavior. It is an indicator for behavior prediction. BI is determined by Attitude toward the Behavior ("AT") and Subjective Norm ("SN"). In addition to these, TPB also takes an individual's Perceived Behavioral Control ("PBC") into consideration.

\section{Methodology}

\section{A. Research Design}

After reviewing the literature concerning purchasing land and houses, the researcher found that there are four studies strongly related to this study: [3], [12], [13]investigated the farmland owners' motives to purchase farmhouses in the urban planning area through interviews, [14] explored the consumers' willingness to purchase and rend land and build houses by the fuzzy analytic hierarchy process, [15] examined factors involved in the process of investing the real estate in Kaohsiung City by the fuzzy analytic hierarchy process, and [16] explored factors involved in the decision making process of purchasing houses through the questionnaire survey. Based on the factors used in these four studies and the researcher's personal experiences, this study categorizes the possible factors influencing farmland purchasing and farmhouse building into attitude, subjective norm, and perceived behavioral control.

Since attitude is a general term, involving personal 
preferences, values, experiences, judgments, knowledge and emotions [17], urban residents' preference to land is categorized into attitude in this study. That is, questions concerning attitude in this study include urban residents' psychological factors and their preferences to land.

As for questions concerning land preference, the study designs related survey questions involving land area, completeness of the land, surrounding natural conditions, land fertility, land value expectancy, significant development projects in the neighborhood, living functions, transportation, distance to the downtown, obnoxious facilities in the neighborhood on the basis of [1], [11], [14], [18]-[21].

In relation to psychological factors, the study designed related survey questions involving the relation between one's economic condition and farmland purchasing and farmhouse building, traditional concept that where there is soil there is wealth, personal preference to farming in the country, personal preference to the slow-paced life in the country, personal preference to the natural environment in the country, more free hours for farming in the country after retirement, growing up in the country in the childhood, personal preference to living in the country according to Ajzen's definition of attitude, [17], [22]-[24].

Since subjective norm involves which important opinion groups influence the general public and how well the public follows their suggestions to purchase farmland and build farmhouses, the study examines definitions of significant opinion groups used in [9], [14], and [25] and defines "significant opinion groups" as land agents, family members, relatives and friends, online advertisements, commercials and flyers and later surveys how well the urban residents follow the significant opinion groups.

About perceived behavioral control, the information and capital which the urban residents can exercise are two main concerns in this study. Moreover, based on [17], [22]-[24], the study designs survey questions involving whether urban residents can have sufficient information about farmland to make decisions, whether urban residents have local acquaintances to get better prices, how much is their loanable fund, whether they have enough capital to buy farmland or build farmhouses.

In relation to the willingness to purchase farmland and build farmhouses, the study employs Ajzen's definition of willingness, together with [1], to design survey questions involving willingness to purchase farmland in the country within six months, willingness to purchase farmland in the country within one year, willingness to build farmhouses in the country within six months and willingness to build farmhouses in the country within one year.

To explore the background of the participants, the study designs questions involving gender, age, educational background, residency, monthly income, purpose of farmland purchase.

The hypotheses of this study are as follows:

1) Urban residents' attitude will influence their willingness to buy farmland and build farmhouses.

2) Urban residents' subjective norm will influence their willingness to buy farmland and build farmhouses.

3) Urban residents' perceived behavioral control will influence their willingness to buy farmland and build

\section{farmhouses.}

\section{B. Participants}

To examine the real station of urban residents' farmland purchasing and farmhouse building in the country, the researcher asked interviewers who lived in Taipei City, Taichung City, and Kaohsiung City to distribute questionnaires. Before the distribution of questionnaires, the interviewers would ask the participants whether they were willing to purchase farmland and build farmhouses in the country. The interviews were conducted only with the participants who were about to purchase farmland and build farmhouses in the country.

270 valid questionnaires were gathered in Taipei City, 230 in Taichung City, and 250 in Kaohsiung City. The questionnaires were distributed from July 1st to August 30th, 2014 and there were 750 valid questionnaires in total.

\section{RESEARCH FINDINGS}

\section{A. Analysis of Participants' Background}

In this study, 500 participants were male (53\%) while 350 participants were female $(47 \%)$. There is no significant difference of gender in this study. As for age, there were 120 participants aged from 31 to $40(16 \%), 185$ participants aged from 41 to 50 (25\%), 215 participants aged from 51 to 60 $(29 \%)$ and the rest aged above $61(30 \%)$. As to educational background, 251 participants owned bachelor's degree $(33 \%), 158$ owned college degree $(21 \%), 152$ owned high school diploma or vocational school diploma, and 189 owned master's degree or above (25\%). Concerning monthly income, 228 participants had a monthly income of 50,001-80,000 NTD (30\%), 189 participants had a monthly income of 30,001-50,000 NTD (25\%), 175 participants had a monthly income below 30,000 NTD (23\%), and 158 participants had a monthly income of above 80,000 NTD (21\%). Regarding the purpose of purchasing farmland , 224 participants answered they purchased the farmland for farming (30\%), 162 participants answered they would build farmhouses on it for their own residency (22\%), and 152 answered for the increased value (20\%), 120 answered for building farmhouses (16\%), and 92 answered they would rent the farmland they purchased to other citizens (12\%). It is clear that the main purposes of purchasing farmland in the country are farming work, building farmhouses and any possible added values.

\section{B. Analysis of Descriptive Statistics}

\section{1) Analysis of descriptive statistics on attitude}

The top six questions which most participants agreed with are (1) land value expectancy will influence my preference to the land $(\mathrm{M}=4.11, \mathrm{SD}=.61)$, (2) completeness of the land shape will influence my preference to the land $(\mathrm{M}=$ $4.07, \mathrm{SD}=.52$ ), (3) significant development projects in the neighborhood will influence my preference to the land $(\mathrm{M}=$ $3.98, \mathrm{SD}=.45)$, (4) surrounding natural conditions will influence my preference to the land $(\mathrm{M}=3.92, \mathrm{SD}=.39)$, and (5) obnoxious facilities in the neighborhood such as cemeteries will influence my preference to the land $(\mathrm{M}=$ $3.87, \mathrm{SD}=.49$ ) and I like to do farming work in the country $(\mathrm{M}=3.87, \mathrm{SD}=.55)$. 


\section{2) Analysis of descriptive statistics on subjective norm}

The top five questions which most participants agreed with are (1) my family members' opinions will influence whether I decide to purchase farmland or build farmhouses in the country $(\mathrm{M}=3.99$, $\mathrm{SD}=.55)$, (2) I will ask my family members' for their opinions before I go purchasing farmland and building farmhouses in the country $(\mathrm{M}=3.92, \mathrm{SD}$ $=.49$ ), (3) my relatives' and friends' opinions will influence whether I decide to purchase farmland and build farmhouses in the country $(\mathrm{M}=3.78, \mathrm{SD}=.61)$, (4) online information will influence whether I decide to purchase farmland or build farmhouses in the country $(\mathrm{M}=3.58, \mathrm{SD}=.62)$, and (5) land agents' opinions will influence whether I decide to purchase farmland or build farmhouses in the country $(\mathrm{M}=$ 3.57, $\mathrm{SD}=.39$ ).

\section{3) Analysis of descriptive statistics on perceived behavioral control}

The top three questions that most participants agreed with are (1) I can afford the expenses for purchasing farmland and building farmhouses $(\mathrm{M}=3.81, \mathrm{SD}=.47)$, (2) I have sufficient capital to afford the expenses of farmland purchasing and farmhouse building $(\mathrm{M}=3.77, \mathrm{SD}=.50)$, and (3) I have local acquaintances to get better prices ( $\mathrm{M}=$ $3.72, \mathrm{SD}=.50)$.

\section{4) Analysis of descriptive statistics on willingness to purchase farmland}

Based on the data analysis, it is found that participants are willing to purchase farmland within six months $(M=3.92$, $\mathrm{SD}=.58)$, participants are willing to purchase farmland within one years $(\mathrm{M}=3.99, \mathrm{SD}=.61)$, participants are willing to build farmhouses within six months $(M=4.02$, $\mathrm{SD}=.68)$, and participants are willing to build farmhouses within one year $(\mathrm{M}=3.95, \mathrm{SD}=.41)$. The findings suggest that, within 6 months or within one year, participants are willing to and even agree to purchase farmland and build farmhouses $(M=4.00)$. It is clear that the participants in this study are highly willing to purchase farmland and build farmhouses in the country.

\section{Linear Structural Equation Model}

TABLE I: TABLE OF THE THRESHOLDS OF THE LINEAR STRUCTURAL EQUATION MODEL

\begin{tabular}{llll}
\hline \multirow{4}{*}{ Model-fit Evaluation } & \multicolumn{3}{c}{ Model in this study } \\
\cline { 2 - 4 } & Thresholds & Fit Measures & Remarks \\
\hline Absolute Fit Indexes & & & \\
$\quad$ Likelihood-Ratio $\chi^{2}$ & $p .05$ & $81.03^{* * *}$ & Good \\
GFI & $\geqq .90$ & .910 & Good \\
AGFI & $\geqq .90$ & .903 & Good \\
RMSEA & $\leqq .08$ & .078 & Good \\
\hline Incremental Fit Indexes & & & Good \\
\hline NFI & $\geqq .90$ & .912 & Good \\
CFI & $\geqq .90$ & .920 & Good \\
\hline Parsimonious Fit Indexes & & .772 & Good \\
\hline PGFI & $\geqq .50$ & 2.02 & \\
Likelihood-Ratio $\chi^{2} / d f$ & $\leqq 3$ & &
\end{tabular}

To examine whether the model in the study fit the participants' opinions, this study illustrated key examination items and thresholds as Table I. It is evident that all the examination items were good, which reflects that the model in this study match the participants' opinions. The research model used in this study not only matches the hypotheses in the related theories but also reflects urban residents' actual opinions of farmland purchasing and farmhouse building in the country.

Based on the analysis of results of the linear structural equation model, the top three influential factors that strongly affect the participants to purchase farmland in the country are attitude $(\beta=.501)$, subjective norm $(\beta=.438)$, and perceived behavioral control $(\beta=.331)$. Similarly, the top three influential factors that affect the participants to build farmhouses in the country are attitude $(\beta=.430)$, subjective norm $(\beta=.398)$, and theperceived behavioral control $(\beta=$ $.229)$.

\section{DISCUSSION AND SUGGESTIONS}

\section{A. Discussion}

\section{1) Attitude is the strongest factor affecting the} respondents to purchase farmland or build a farmhouse

Through a linear structural equation model, the research discovered that attitude has the strongest impact to the respondents when they considered purchasing farmland or building a farmhouse in the countryside. Similarly, [21] discovered in her research (2013) that transportation construction, farmland area, and switching policies were the main factors affecting farmhouse trades in Puli Township between 1996-2011, which is similar to the attitude of land preference studied in this research. Additionally, if the respondents also have psychological factors towards land, such as the traditional Chinese concept of "where there is soil there is wealth" and that the countryside is suitable for leisure and living, the attitude will easily become an important impact factor to purchase farmland or build a farmhouse. It indicates that the respondents are very concerned about relative issues of land, especially the expected appreciation for the land value when purchasing land in the countryside. It also means that urban citizens have a higher willingness to purchase farmland with appreciation potential. This discovery is in accord with the discovery of [20] and [26] too, in which farmland has been regarded as an asset rather than the factor of production, and the appreciation and investment are most farmland owners' anticipation. This discovery is also similar to the result regarding respondents' background data. These show that the respondents' main purpose, after buying land in the countryside, is to farm, build a farmhouse, and then wait for the appreciation. Therefore, the respondents naturally paid considerable attention in land characteristics of the attitude topic.

\section{2) Before buying land for building a farmhouse, the respondents consulted the citizens they trusted the most}

In the case of buying land for building a farmhouse in the countryside, the respondents cared for their family's opinions the most, then relatives and friends, Internet information, and land brokers, respectively. As for not trusting or relying upon the land broker's suggestions or information, many respondents were concerned about brokers making the maximum price difference for their own benefit, which meant most respondents worried about information asymmetry or a bad deal when purchasing land in the countryside through a broker. They doubted the land-related issues introduced by any broker, so they would 
rather ask for relatives' or friends' assistance, search the land's information online, or visit the place and talk to the locals in-person a couple of times, in order to learn about the land and its surroundings.

\section{3) The respondents are confident of being able to afford the expenses for purchasing farmland and building a farmhouse in the countryside}

From perceptual control to behavioral control, the first three topics the respondents agree with are, sequentially, "I can afford the expenses for purchasing farmland and building a farmhouse", "I have enough capital to pay the expenses for purchasing farmland and building a farmhouse", and "I know someone there who can help me get a better price". This means that the parts that the respondents feel the most confident with in terms of purchasing land and building a farmhouse in the countryside are that they can afford the related expenses of purchasing land and building a farmhouse, they have enough funds, and they know some local people to get a favorable price. Additionally, this research also discovered that the respondents scored lower in the topic of "My loanable capital amount can afford the related expenses of purchasing farmland and building a farmhouse". This also means that these respondents tend to purchase land and build a farmhouse with their cash instead of getting loans in regards to purchasing land and building a farmhouse in the countryside.

\section{B. Suggestions}

With respect to the strong tendency of purchasing land in the countryside, this research tries to figure out a way to guide this tendency into the paths that could benefit agriculture development and use lands properly. This research proposes the following suggestion for reference:

1) Local responsible institution (the agriculture department or peasant association of village, town or district) should provide the related information about farmland utilization (including being engaged in farming and building a farmhouse).

2) Local agricultural association should build the partner relationship with landowners.

3) The county and city government should pay attention to the corresponding topics derived from citizens purchasing land and building a farmhouse in the countryside.

\section{REFERENCES}

[1] Z. Q. Lin, The Influence of Farmland Transactions and Farmhouse Building Trend on Farmland Usage, Taipei, Taiwan: Council of Agriculture Executive Yuan, 2006, pp. 99-105.

[2] M. C. Chen, "The institutional analysis of agricultural buildings on the farmland in the Taiwan's country area," Taiwanese Journal of Rural Studies, vol. 4, pp. 41-74, 2004.

[3] Executive Yuan, A Study of Converting Farmland to Low-Density-High-Quality Community and its Implementation Package, Taipei, Taiwan: Council for Economic Planning and Development, 2004, pp. 23-40.

[4] C. J. Armitage and M. Conner, "Efficacy of the theory of planned behaviour: A meta-analytic review," British Journal of Social Psychology, vol. 40, pp. 471-499, 2001.

[5] H. B. Chen and X. C. Cai, "The study of theory of planned behavior (tpb) in the case of national Penghu university students' healthy diet behavior intention," Journal of Sport, Leisure and Hospitality Research, vol. 7, no. 3, pp. 78-103, 2012.
[6] P. Y. Chu and J. F. Chiu, "Factors influencing household waste recycling behavior: Test of an integrated model," Journal of Applied Social Psychology, vol. 33, pp. 604-626, 2003.

[7] S. Y. Lai, S. Q. Qian, and F. L. Cai, "Using tpb theory to discuss the tourists' intention of museum - A case of the Kaohsiung museum of fine arts," Asia-Pacific Economic and Management Review, vol. 16, no. 2, pp. 39-59, 2013.

[8] W. B. Lin and S. F. Yang, "The research of model construction affecting use intention in e-learning market - Application of fuzzy-neural network method," Sun Yat-Sen Management Review, vol. 13, no. 2, pp. 721-748, 2005.

[9] Y. W. Wang, H. L. Ke, Y. Y. Yan, Y. Z. Lin, B. L.Lin, Z. Y. Hu, and X. L. Huang, "The application of the theory of planned behavior to understanding factors associated with adolescent's intention to quit smoking: A college of medicine and management," The Taiwan Journal of Oral Medical Sciences, vol. 28, no. 1, pp. 4-22, 2013.

[10] I. Ajzen, "The theory of planned behavior," Organizational Behavior and Human Decision Processes, vol. 50, pp. 179-211, 1991

[11] D. Hite, "Information \& bargaing in markets environmental quality," Land Economic, vol. 74, pp. 303-316, 1996.

[12] C. F. Jian, "The study of strategic management under national spatial planning," Land Issues Research Quarterly, vol. 4, no. 2, pp. 2-14, 2005.

[13] C. Z. Liu and B. W. Huang, "A study on farmland management and issues of construction of farmhouses on farmland," Socioeconomic Law and Institution Review, vol. 34, pp. 305-336, 2004.

[14] J. H. Cai, "The study of leisure-time house buying and using behavior: The case study of di zhonghai community and baenian community," master's thesis, Dept. Urban Planning, National Chung Hsing University, Taichung, 1997.

[15] M. Z. Liao and J. Z. Zhou, "A study on Kaohsiung city's real estate using the fahp method," Journal of Global Business Operation and Management, vol. 3, pp. 181-191, 2011.

[16] C. X. Wu, "The empirical comparison on housing choice models and household bid-rent models," master's thesis, Dept. Urban Planning, National Cheng Kung University, Tainan, 2001.

[17] W. O. Bearden and J. E. Teel, "Selected determinants of consumer satisfaction and complaints reports," Journal of Marketing Research, vol. 20, pp. 21-28, 1983.

[18] Z. M. Zhang, "Exploring the farmland division and limitation of 0.25 hectares farmhouse building," Agriculture Policy \& Review, vol. 11, pp. 58-61, 2003.

[19] T. A. King, "The demand for housing: Alancastrian approach," Southern Economic Journal, vol. 3, pp. 1077-1087, 1976.

[20] A. F. Huang, "A study on the policy of controls for the farm housing construction in urban planning area after revision of agricultural development act," master's thesis, Dept. Land Economics \& Administration, National Taipei University, Taipei City, 2003.

[21] B. L. Wei, "A study on the construction and transaction of farmhouse," master's thesis, Dept. Management and Development, Chang Jung Christian University, Tainan, 2013.

[22] Q. D. Zhuang and J. C. Zhao, e-Conomics Book, Taipei, Taiwan: Huatai Culture, 2000, pp. 120-129.

[23] V. A. Zeithaml, M. J. Bitner, and D. D. Gremler, Services Marketing: Integrating Customer Focus across the Firm, 4th ed. New York: McGraw-Hill, 2006, pp. 25-44

[24] J. F. Engle, D. T. Kollat, and R. D. Blackwell, Consumer Behavior, 4th ed. Hinsdale, IL: Dryden Press, 1984, pp. 12-20.

[25] F. Norton, "The case theorem and sub optimization in marketing channels," Marketing-Science, vol. 6, no. 3, pp. 268-285, 1987.

[26] G. X. Wu, "A review and outlook of the utilization of agricultural land in Taiwan," Journal of the Land Bank of Taiwan, vol. 43, pp. 1-28, 2000 .

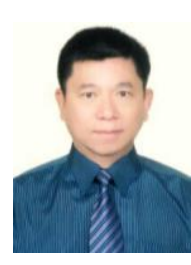

Jung-Tsun Liu was born on February 19, 1958 in Kaohsiung, Taiwan, ROC. He is a $\mathrm{PhD}$ candidate in Institute of Management, Chang Jung Christian University, Taiwan (R.O.C.).

From 2000 to 2005, he was with the Department of Law Faculty of Law and Political Taiwan ROC National Kaohsiung University; From 2006 to 2008, he completed a master's degree thesis and master's program in the Taiwan ROC Department of Land Management and Development Evergreen State University. He graduated in 2013 from the Institute of Management doctoral Evergreen University.

His current occupation is opened lands village people with disabilities receive free legal advice to the firm on "real estate development, finance, planning, property trust business for enterprises to help solve the puzzles on business across many industries. 